\title{
WHAT KIND OF - TERRIBLE - COUNTRY IS THIS? WHAT KIND OF PEOPLE...? IN RESPONSE TO MARTA BUCHOLC
}

\author{
Mirosława Grabowska \\ University of Warsaw
}

I look at the cover of my book and see a priest "hearing the confession of a worker. The two are surrounded by a crowd of strikers on their knees, awaiting their turn to confess and be absolved" (Bucholc 2018: 143). The reviewer, Marta Bucholc, recognised the priest to be Henryk Jankowski, who is accused - and she repeats the accusations - of being an informant of the Security Service, and also of pride, greed, gluttony, and the sexual abuse of children. Even if all these accusations were fully justified, they do not invalidate the truth of that moment, that time.

In the same way, the various accusations against Lech Wałęsa, including of cooperation with the Security Service, do not lessen his leadership of Solidarity and the strike in the Gdańsk Shipyard. As an aside, is it an exceptional situation that someone who is far from ideal should accomplish something significant? Or create some great work? ${ }^{1}$ What Lech Wałęsa and Father Jankowski did in 1980 affected the history of our country. Historians (and the Lord) have called the latter to account for his sins - the courts were not in time.

I am not a historian. I have not studied the cooperation of priests and monks with the Security Service, nor do I know of a reliable work on the

\footnotetext{
${ }^{1}$ For instance - to avoid current Polish examples - Ezra Pound was a great poet even though he was fascinated by fascism and during the Second World War gave a propaganda speech on Italian radio.
} 
subject. It should not be forgotten, however, that priests and monks were a social category "under special supervision." Each one, at the moment of entering the seminary or beginning a novitiate in an order, would have had a file begun on him in which compromising evidence would be collected and might be used to incline him to cooperate. We do not know the proportions: how many there were for whom compromising evidence was found and who were thus persuaded to cooperate. I do not want to guess what would be the outcome of the use of such a strategy in regard to the academic milieu.

Undoubtedly, it is not only priests and monks who engage in the sexual abuse of children, but in their case it arouses special moral outrage. But again, the scale of the phenomenon has not been credibly diagnosed. It is worth remembering that the communist system paradoxically "spared" the clergy many opportunities: in Poland before 1989, the Catholic Church basically did not run schools with dormitories, boarding houses, orphanages, etc., and thus circumstances allowing for the sexual abuse of minors were rarer than in Anglo-Saxon countries. There is thus no basis to assume that the scale of the phenomenon was similar. Independently of the scale, however, every such instance, whether occurring within the Church or outside of it, and whether perpetrated by a member of the clergy or a lay person, should be investigated ex officio and tried by a state court.

If I had to decide again about the cover of my book, I would again choose that photo of confession during the strike in the Gdańsk Shipyard: a photo of the "simple but powerful piety of hard-working people, and the brave priest supporting them spiritually in their struggle against the common enemy" (Bucholc 2018: 143).

But the question of our country or society is larger than the appraisal of an individual priest. What kind of a country is it, where

Catholic religiosity [...] contributes to the dark force fuelling hostility towards refugees as well as towards sexual, national, ethnic, and religious minorities - and in fact all minorities - and a stronghold of political support for the party directly responsible for demolishing the democratic rule of law in Poland after 2015 [...]. [Where] the clergy are found guilty of child abuse, while bribery, insider trading, and tax fraud involving the highest state and 
Church officials are plausibly alleged, while laws are proposed prohibiting sexual education at schools, and while the idea of effective segregation of the LGBT+ population is advocated and is gaining popular support [...] (Bucholc 2018: 144).

And that's not the whole of it by any means, because there is responsibility for anti-Semitism, and for how doctors, pharmacists, and politicians behave... Are there any Polish sins at all, for which the Catholic Church is not responsible? Has the Church ever done, or is it doing, anything good? Has its teaching had any positive effect?

Let us skip the details, although they are important because cumulated and inflated they provide the image of a "dark force" (what is implied is not affirmed - the Church did not propose the law forbidding sexual education in schools or the segregation of LGBT people, etc.). Very generally speaking, there are two ways to analyse societies: more ideologically or more sociologically. In order for the first method not to have negative connotations, let us call it the "critical" method. Marta Bucholc adheres to the critical approach: there is a certain ideal; there are certain standards to which we compare a given society.

The ideas presented in such an approach can be disputed in two ways: by questioning the ideal (which I will not do, as - I imagine - to a certain degree I share it), or by a sociological analysis, involving the change of social attitudes over time and by a comparison with other societies. I adhere to the second, sociological approach and in this manner I will answer the reviewer's censure and observations. However, even if we unreservedly adopted the critical perspective and were to draw up a detailed accounting of Polish society and the Catholic Church, the balance would not be as unambiguously negative as in the review.

1. First, in regard to the reviewer's opinion that I devote too much space in the book to politics and elections, here I do not agree: I focused on an area in which the effects of religiosity have been consistent and strong, perhaps the strongest.

The Catholic Church has consistently called for participation in elections and did so before other social institutions and authorities. Guided by the hermeneutics of suspicion, we might say that the hidden intention of those appeals was to provide voters - in the Church's interest - for the Law and Justice party. Nevertheless, if we check how believers and practitioners (hereafter, a "practitioner" means a person attending Church at least once a week) voted in the 2019 parliamentary elections, it emerges 
that only (or as many as) 55\% of believers voted for Law and Justice. The rest chose other parties: 19\% voted for Civic Coalition, centred on Civic Platform, and nearly $8 \%$ for Democratic Left Alliance (or more precisely, the coalition centred on Democratic Left Alliance). Two-thirds of practitioners voted for Law and Justice; over 11\% chose Civic Coalition, over 8\% the Polish People's Party (more precisely, the coalition centred around the Polish People's Party), and nearly 5\% chose the Democratic Left Alliance. More non-believers than believers voted for the Confederation. ${ }^{2}$ This is a voting pattern that is repeated in many European countries: believers (of varying confessions) support conservative parties - because what other parties would they vote for? Radical right-wing parties are supported rather by non-believers, as religiosity does not favour radicalism (including of the right).

Whether such a situation - the connection of religiosity with a single political party - is advantageous for the Church is a separate question. But it is a question that should be addressed to the Church and definitely not to social reality.

To what degree do Law and Justice's voters constitute that "dark force"? Nearly $16 \%$ are managerial personnel or specialists with a higher education; over $18 \%$ have a higher education; $13 \%$ are under 34 years of age. Of course, Civic Coalition's electorate is located higher in the social structure (41\% are managerial personnel or specialists with a higher education) and better educated ( $40 \%$ have a higher education), while the Confederation's electorate is much younger $\left(40 \%\right.$ are under 24 years of age). ${ }^{3}$ But should we raise the voting age in order to prevent the possibility of nationalists getting into the Sejm? Should participation in elections depend on having passed the school-leaving exam? Perhaps Civic Coalition's problem, and to a certain extent Democratic Left Alliance's, too, is that they do not recognise or represent either the interests or the convictions of inhabitants of the countryside (where $39 \%$ of the population resides) or people of lower social levels (those with less education, and lower household incomes)?

Perhaps, thus, that "dark force" was tricked by Law and Justice and allowed itself to be deceived? If so, it has been a long-lasting mental disability because $94 \%$ of those who voted for Law and Justice in the parliamentary elections in 2015 chose the same party in 2019. The electoral preferences of Civic Platform's supporters in 2015 were maintained to a certain degree in 2019 , when $71 \%$ voted for Civic Coalition. And the rest? Nearly $16 \%$

\footnotetext{
${ }^{2}$ My own analysis of data from the CBOS survey in November 2019 on a random sample, $n=996$.

${ }^{3}$ My own analysis of data from the CBOS survey in November 2019 on a random sample, $n=996$.
} 
of Civic Platform's voters of 2015 chose Democratic Left Alliance, and the remainder divided their votes between the Polish People's Party, the Confederation, and even Law and Justice. ${ }^{4}$ Of what can we accuse them? Of betrayal? Of mental eclipse? Or can their electoral behaviour rather be explained by disappointment with the policies of a party they earlier supported?

I would be very careful in labelling party electorates: all are internally varied; each vote is backed by serious motivations - "serious," since the voter wanted to vote (and let us remember that nearly 38\% of those entitled to vote did not bother to go to the polling station).

2. The balance sheet of the Catholic Church's activities should not omit its positive impact on the condition of civil society, which I merely mentioned in passing in my book. Believers and especially practitioners have more trust in people and greater trust in institutions, and trust is an essential element of social capital and a strong driver of civil society. Practitioners, to the highest degree, declare their readiness to help other people. Consequently, to a greater degree they work socially (voluntarily and without payment) on behalf of their community and engage in helping the needy. They are active to a greater degree in civic organisations. The Public Opinion Research Center (CBOS) has many times documented these pro-civic attitudes of believers and practitioners (see Boguszewski 2016, 2018; Głowacki 2018; Grabowska 2012). It is characteristic that this research is not to be found in the news and does not reach the media and public opinion.

3. The Catholic Church as an institution and Catholicism as a confession has had a fundamental importance for Polish society - for historical reasons: I wrote extensively about it in my book. It is also obvious to many foreign authors, historians and sociologists, among others, José Casanova (1994; Polish ed. 2005) and Charles Taylor (2007). Whether that tradition survived the Second World War, the Holocaust, and communism, what survived of it and to what degree - these are the things I tried to grasp and present in my book.

Marta Bucholc raises several issues in regard to which she ascribes social attitudes to the influence of the Church, and perhaps to Catholicism: these are anti-Semitism, the attitude to refugees, moral questions such as the attitude to abortion and euthanasia, in vitro insemination, sex education, LGBT... (which have become political - in this respect I am in complete agreement with her). She criticises me for not having devoted enough

\footnotetext{
${ }^{4}$ My own analysis of data from the CBOS survey in November 2019 on a random sample, $n=996$.
} 
attention to these matters. I did not devote attention to them, it's true I would have had to write a second book on these topics. But in response to the review, I would like to make some brief supplementary comments.

(a) I treated the attitude to abortion as an example of a moral question in which positions are affected by the influence of religiosity and the Church. Obviously, religiosity favours the rejection of abortion. But even the majority of practitioners accept the right to interrupt a pregnancy in the instances listed in the law in force: when the life or health of the mother is endangered, when the pregnancy is the result of a crime (rape, incest), or when it is known that the child will be born impaired. They do not accept abortion when a woman is in a difficult material or personal situation, or simply does not want to have a child, but the majority of non-practising persons also do not accept abortion in these situations. ${ }^{5}$ The case is similar with rejecting euthanasia (48\% reject it, practitioners much more often), ${ }^{6}$ approbation for in vitro insemination when a married couple cannot have a child $(76 \%$ approve of it, practitioners less often), ${ }^{7}$ and sex education (84\% approve of sex education in schools, practitioners less often) (see Kawalec 2019).

(b) The next issue, the attitude to LGBT people, could be dealt with in a like manner: while society has a generally unfavourable attitude towards gays and lesbians, the attitude of believers and practitioners is even worse (on a 7-point scale, where " 1 " signifies great dislike and "7" full acceptance, the average among the total of those surveyed was 3.53, for believers 3.40, and for practitioners, 3.23, and thus all the averages are located below the middle of the scale, and reflect dislike). The same appears in the perception of homosexuality as a deviation from the norm, and in the rejection of the possibility of two persons of the same sex entering a formal partner relationship, ${ }^{8}$ not to mention the adoption of children. But since 2001 (when CBOS began monitoring the issue) specific opinions and the general attitude have been changing - very slowly, it is true - in the direction of slightly greater tolerance and openness towards gays and lesbians

\footnotetext{
${ }^{5}$ My own analysis of data from a CBOS survey in October 2016 on a random sample, $n=937$. It should be added that although attitudes to abortion are characterised by stability, they may have undergone change since 2016 - that is, the attitudes, not their dependence on religiosity.

${ }^{6}$ More precisely, shortening the life of terminally ill patients at their request (see Boguszewski 2013). Also my own analysis of data from a CBOS survey in July 2013 on a random sample, $n=$ 1,005 , with the reservation that these attitudes may have changed.

7 See Boguszewski 2015, with again the reservation that these attitudes may have changed.

${ }^{8}$ It should be noted that $48 \%$ of Polish society considers homosexuality to be morally reprehensible, while the societies of all the post-Soviet and post-communist countries (with the exception of the Czech Republic) condemn homosexuality to a greater or much greater degree (Estonia 64\%, Latvia 68\%, Lithuania 72\%, and Hungary 53\%). See: https://www.pewforum.org/2017/05/10/religious-belief-and-national-belonging-in-central-and-eastern-europe/, accessed 21.12.2019.
} 
and their needs. ${ }^{9}$ Should it be expected that the Catholic Church will act to hasten the process in toto? Or will its position rather attempt qualification: homosexual persons - yes; some of their rights - yes; full equality of rights for homosexual couples - no? ${ }^{10}$

(c) The attitude to refugees and migrants is difficult to analyse: various studies have provided varying results. In international studies, Polish society falls below the average: better than the Hungarians, but worse than the societies of Western Europe, which are friendlier to refugees. ${ }^{11}$ In comparative studies conducted by CBOS in cooperation with research centres in the Czech Republic, Slovakia, and Hungary, the Poles emerge (that is, emerged) somewhat better than their neighbours: fears of an influx of refugees were strongest among Czechs and Slovaks; the majority of Hungarians, on the one hand, accepted providing shelter to refugees, on the other hand, two-thirds were against accepting refugees from the Middle East and Africa (Bożewicz 2016; Kowalczuk 2015). It should be remembered, however, that Hungary had already experienced a massive influx of refugees and the problems related with it. Poles, however, were more often inclined to offer shelter to refugees, especially refugees from Ukraine, from the territories involved in armed conflict. ${ }^{12}$

Nevertheless, the conclusion that it is worse elsewhere is no comfort, as the attitude to accepting refugees and the attitude to migrants has been changing over time and not for the better. In the last surveys on the subject (from 2017) 63\% of the respondents (three times more than in May 2015) did not agree that Poland should accept refugees from countries involved in armed conflict (without specifying where). We do not want to accept refugees from the Middle East and Africa, and especially from Muslim countries $-74 \%$ of the respondents were against it, even if we were threatened with the loss of EU funds. On the other hand, a majority (61\%) were willing to accept the inhabitants of Ukraine migrating from the territories subject to military operations (Feliksiak 2017).

\footnotetext{
${ }^{9}$ My own analysis of data from a CBOS survey in April 2019 on a random sample, $n=1,064$ (see also Bożewicz 2019).

${ }^{10}$ In the spirit of the declaration by Archbishop Stanisław Gądecki, President of the Polish Episcopal Conference on 8 August 2019: people belonging to milieus of so-called sexual minorities are our brothers and sisters, for whom Christ gave his life and whom he equally wants to lead to salvation. Respect for specific persons cannot, however, lead to the acceptance of an ideology whose aim is to bring about a revolution in social mores and interpersonal relations. Pope Francis holds a similar position on the question. See https://episkopat.pl/przewodniczacy-episkopatu-o-lgbt-szacunekdo-osob-nie-moze-prowadzic-do-akceptacji-ideologii-2/, accessed 22.12.2019.

${ }^{11}$ See https://www.pewresearch.org/fact-tank/2019/08/09/people-around-the-world-express-moresupport-for-taking-in-refugees-than-immigrants/, accessed 21.12.2019.

12 A study in 2017 had similar findings (see Feliksiak 2017).
} 
It is true that believers and practitioners are slightly more likely to be against Poland accepting refugees $(63 \%$ of all respondents, $66 \%$ of practitioners) and accepting Muslims, even when a loss of EU funds is threatened ( $74 \%$ of all respondents, $75 \%$ of practitioners), but - as can be seen these are not large differences (although they are statistically significant). In regard to accepting Ukrainians, there is no dependence on religiosity, that is, believers and practitioners do not differ from the whole of society, and, like the general population, are inclined to accept refugees from Ukraine (61\% of respondents were for accepting them, $61-62 \%$ of believers and practitioners). ${ }^{13}$

It might be wondered whether the unfavourable change in attitudes resulted from the extensive news coverage of terrorist attacks, ${ }^{14}$ or from the media discourse, or finally from Law and Justice policy, which consistently rejects the acceptance of refugees by our country. However, the Catholic Church has spoken many times on the question of refugees. ${ }^{15}$ It might be wondered whether such statements were not too late, and whether the Church tried too little to change the attitudes of the faithful and, indirectly, the attitude of the whole society. Whether, given an attitude characterised by such determination (we won't accept Muslims even though we might lose by not doing so), more energetic action by the Church would have been effective, is another question.

(d) Finally, the problem of anti-Semitism. I am not competent to analyse the attitude of the Catholic Church to Judaism and the Jews. We can agree, I hope, that it has been historically variable and that it is presently better than it was in the past. In the Second Republic of Poland, in a country in which the Jewish community constituted nearly $10 \%$ of the population, slightly over 3 million people declared themselves to be of the Jewish faith and nearly 2.5 million declared Yiddish to be their native language. ${ }^{16}$

\footnotetext{
${ }^{13}$ My own analysis of data from a CBOS survey in October 2017 on a random sample, $n=948$.

${ }^{14}$ In 2015, in Paris in January and November, in 2016 in Nice in July and in Berlin in December, in 2017 in London in March and June and in Barcelona in August, in 2018 in Carcassonne and Trèbes in March and in Strasbourg in December, to mention only the most widely reported attacks in Europe.

15 The statements and homilies of Archbishop Stanisław Gądecki, President of the Polish Episcopal Conference, including on 2 July 2017, see https://episkopat.pl/abp-gadecki-w-sprawie-uchodzcowkierunek-wskazuje-jezus-nie-politycy/, accessed 4.01.2020; the so-called Twenty Points of Activities on Migrants and Refugees: https://episkopat.pl/dwadziescia-punktow-dzialalnosci-ws-migrantowi-uchodzcow/, accessed 4.01.2020; the Council of the PEC on Migration: a Christian should see a brother in the refugee, and not a problem (27 September 2019) see: https://episkopat.pl/rada-kepds-migracji-chrzescijanin-powinien-widziec-w-migrancie-brata-a-nie-problem/, accessed 4.01.2020. ${ }^{16}$ In the Population Census of 1931 - see: GUS RP. Statystyka Polski, Series C, folder 94A. Warsaw 1938, Tab. 10, p. 15.
} 
To generalise, the Catholic Church treated Jews as outsiders, and individual hierarchs and priests approved of anti-Semitism; they viewed anti-Jewish actions (ghetto benches at universities, pogroms) with tolerance and even considered them to be manifestations of patriotism.

In 2018, a large international study was conducted, surveying 16,500 persons from $12 \mathrm{EU}$ countries identifying as Jews (422 persons from Poland participated). In their appraisal - in regard to anti-Semitism - our country does not come out very well: $39 \%$ of the respondents indicated anti-Semitism to be a very large problem (many fewer than in France, fewer than in Germany and Belgium, more than in the United Kingdom and Hungary, and many more than in Denmark). The respondents (70\%) consider that Poles are convinced that Jews have too much power in Poland, and that Jews make use of the Holocaust for their own aims $(67 \%)$. In Poland the largest share $-32 \%$ of the respondents - were witness in the last year to other Jews being verbally insulted and/or physically attacked; $21 \%$ of the respondents had experienced insulting commentary or threats; $20 \%$ had experienced insulting commentary online and on social media; $15 \%$ had experienced insulting gestures or hostile glances (fewer than in Germany, the Netherlands, and Belgium; more than in Denmark, in Hungary, the United Kingdom, France, and Belgium). Most - 91\% of the respondents - consider that the government is not making efforts to combat anti-Semitism. ${ }^{17}$ Although in many respects our country does not come out that badly - and the survey is not representative - it is not possible to be indifferent to the feelings and opinions of over 400 of our fellow citizens.

In the latest CBOS survey concerning Poles' perception of Jews and Polish-Jewish relations, it is visible that the image of Jews is strongly rooted in the past, especially in the times of the Holocaust. At the same time, the ambivalent stereotype - creating admiration and resentment - of the Jew as a person with business interests, a merchant or a banker, has persisted. The majority of Poles $(55 \%)$ consider that in a time of war more persons helped the Jews than reported them or murdered them. But the conviction prevails that the murders and pogroms committed by the Poles against the Jews should be remembered (many people expressed compassion for the victims and condemned the perpetrators of the crimes) (Roguska 2015). Emotional reactions to the Holocaust did not, practically, depend on the

\footnotetext{
${ }^{17} \mathrm{https} / /$ fra.europa.eu/sites/default/files/fra_uploads/fra-2018-experiences-and-perceptions-of antisemitism-survey_en.pdf, accessed 4.01.2020; for a Polish summary, see: https://fra.europa. $\mathrm{eu} /$ sites/default/files/fra_uploads/fra-2018-experiences-and-perceptions-of-antisemitism-surveysummary_pl.pdf, accessed 4.01.2020.
} 
religiosity of the respondents: believers and non-believers, practising and non-practising, in equal measure expressed compassion for the victims, were moved by their fate, and as Poles felt shame at the thought of the crimes committed by Poles against Jews. ${ }^{18}$

It is not hard to notice that the results referred to here are not very recent. Undoubtedly, attitudes to such an important question should be monitored more systematically. A certain substitute for such monitoring is the annual CBOS survey on attitudes to nationalities (national groups, ethnic groups). The respondents are asked to rate the degree of their liking for a given national group on a 7-point scale. ${ }^{19}$ Since the first survey in 1993, liking for the decided majority of nations has grown: in this time, the condition of Polish society improved; we entered the European Union; we began to travel. Liking for Jewish people also grew (from 15\% in 1993 to $31 \%$ in 2019), although they still belong to one of the less liked groups (Omyła-Rudzka 2019). However, believers and practitioners do not differ much from the rest of society: the average on the scale for all respondents is 4.0 (which might be interpreted as indifference - neither liking nor dislike), and for both believers and practitioners 3.8 (which might be interpreted as weak dislike). ${ }^{20}$

For such results, what "grade" would the reviewer give Polish society, and Polish Catholics?

The point of my response to Marta Bucholc's review is not to brandish surveys and percentages. The reviewer is not obliged to follow the results of various studies, although - I repeat - it is typical that she knows and refers to certain data and not to others. Certain findings do not make their way into the media and public opinion. Confirmation of the anti-Semitism of Polish society always finds a place in the news, while the finding that the attitude to Jews is improving does not.

However, it is clear that:

- first, Polish society had and has its moments of glory, of praiseworthy events, and its dark moments, its shameful events, while on a daily basis it exhibits various shades of greyness;

\footnotetext{
${ }_{18}$ My own analysis of data from a CBOS survey in July 2015 on a random sample, $n=1044$.

19 On a scale where " 1 " indicates dislike and " 7 " liking.

${ }^{20}$ My own analysis of a CBOS survey in January 2019 on a random sample, $n=928$.
} 
- second, the Catholic Church influences attitudes and opinions - in some spheres very strongly and in others weakly; but

- third, the faithful of the Catholic Church, even those who practise systematically, do not constitute an army that votes as the leader commands. They do not have uniform convictions; they are different, and sometimes they are critical of the Church as an institution. The expectation that the Church will change mere mortals into angels is a naïve expectation;

- fourth, institutionally the Church is not free of sin. Sometimes, maybe at present, it lacks outstanding leaders: charismatic leaders, intellectuals and theologists, moral authorities, social activists and politicians. Well, there are fat years and lean years, just as in science, and at the university. Should we withdraw our reverence for and faith in the university as an institution because in a given place and time it is doing poorly? Charisma and talent cannot be planned; neither the university nor the Church can be "managed" in such a way as to achieve those things. The only thing to do is to do one's bit and wait - the faithful can pray.

To conclude, I would like to make an appeal and offer thanks. Marta Bucholc writes that the image of Poland I present is different from "the one we know from the daily news." It is different - I treat that as a compliment. At the same time, I want to appeal to everyone interested in the subject: we should rely less on the news and more on our own observations and experiences, and more on research. And I sincerely want to thank the reviewer: in a time when other people's books are not read - maybe their articles but not their books - Marta Bucholc disinterestedly, from pure scholarly motivations, read my book and wrote a review that inspired me to dig out numerous surveys and to clarify my position, for myself and I hope for others.

Transl. Michelle Granas

Bibliography:

/// Boguszewski R. 2013. Wartości i normy, CBOS research communiqué no. $111 / 2013$.

/// Boguszewski R. 2015. Opinie o dopuszrzalności stosowania zaptodnienia in vitro, CBOS research communiqué no. 96/2015. 
/// Boguszewski R. 2018. Aktywnośc Polakón w organizacjach obywatelskich, CBOS research communiqué no. 29/2018.

/// Boguszewski R., ed. 2016. Opinie i Diagnozy, vol. 35: Społeczeństwo obywatelskie w Polsce A.D. 2016 [Civil society in Poland, A.D. 2016].

/// Bożewicz M. 2016. Stosunek do przyjmowania uchodźcón w Polsce i w Czechach, CBOS research communiqué no. 54/2016.

/// Bożewicz M. 2019. Stosunek Polaków do zwiazków homoseksualnych, CBOS research communiqué no. 90/2019.

/// Bucholc M. 2018. "Ubi Caritas...: Mirosława Grabowska, Bóg a sprawa polska. Poza granicami teorii sekularyzacji," Stan Rzeczy, vol. 2(15), pp. 143-152.

/// Casanova J. 1994. Public Religions in the Modern World, University of Chicago Press [Polish ed.: Religie publiczne w nowoczesnym świecie, Zakład Wydawniczy Nomos, 2005].

/// Feliksiak M. 2017. Stosunek do przyjmowania uchodźcón, CBOS research communiqué no. 163/2017.

/// Głowacki A. 2018. Czy Polacy sq altruistami? CBOS research communiqué no. 31/2018.

/// Grabowska M., ed. 2012. Opinie i Diagnozy, vol. 22: Społeczeństwo obywatelskie w Polsce A.D. 2012 [Civil society in Poland, A.D. 2012].

/// GUS RP. Statystykea Polski, Series C, folder 94A. Warsaw 1938, Tab. 10, p. 15.

/// Kawalec I. 2019. Opinie o warsqawskiej karcie lgbt+ i edukacji seksualnej w sqkołach, CBOS research communiqué no. 66/2019.

/// Kowalczuk K. 2015. Stosunek do uchodźcón w krajach Grupy Wyszehradzkiej, CBOS research communiqué no. 151/2015.

/// Omyła-Rudzka M. 2019. Stosunek do innych narodów, CBOS research communiqué no. 17/2019.

/// Roguska B. 2015. Postrzeganie Żydów i stosunków polsko-żydowskich, CBOS research communiqué no. 112/2015.

/// Taylor Ch. 2007. A Secular Age, Harvard University Press. 
/// Mirosława Grabowska - Warsaw University professor, and since 2008 the director of CBOS (Public Opinion Research Center). Her interests and research include the sociology of politics and of religion. Key publications: Budowanie demokracji [Building democracy] (written with Tadeusz Szawiel, published in 2001 and republished in 2003); Podziat postkomunistyczny. Spoteczne podstawy polityki w Polsce po 1989 roku [Post-communist cleavage. The social bases of politics in Poland after 1989] (2004); Bóg a sprawa polska. Poza granicami teorii sekularyzacji [God and the Polish cause. Beyond the limits of secularisation theory]. She has been a visiting scholar at Stanford University (USA), a fellow at the Institute for Advanced Study, Princeton (USA), visiting professor at the University of Wisconsin - Madison (USA) and Mainz University (Germany).

ORCID: https://orcid.org/0000-0002-4652-1288

Email: grabomir@is.uw.edu.pl 